\title{
PARTICULATE MATTER AND CARBON DIOXIDE MONITORING IN INDOOR PLACES
}

\author{
M. RAGAZZI , E.C. RADA, S. ZANONI, G. PASSAMANI \& L. DALLA VALLE \\ Department of Civil, Environmental and Mechanical Engineering, University of Trento, Italy.
}

\begin{abstract}
People spend most of their time in enclosed spaces (e.g., apartments, offices and public buildings). According to research, indoor air quality can be worse than the outdoor air quality (OAQ). Hazardous chemicals found in the air indoors can adversely affect the functioning of the human body and cause many respiratory and circulatory diseases. Little is known about particulate matter (PM) concentration in indoor space of various services and office buildings/facilities (not related to production, i.e. offices, shops, kitchens etc.) and its associated health risk. Similarly, carbon dioxide $\left(\mathrm{CO}_{2}\right)$ is a gas scarcely analyzed in the buildings but it is a good marker of living comfort.

In this study, measurements of $\mathrm{PM}$ and $\mathrm{CO}_{2}$ were taken in indoor environments, poorly investigated in the past. The concentrations of PM were monitored and compared using a GRIMM analyzer model 1.108 in two offices, two printer rooms and two bedrooms, while the levels of $\mathrm{CO}_{2}$ were investigated by means of a Sensordrone low-cost multi-sensor in a computer-room, in addition to the same offices and bedrooms already under study.

The indoor PM concentration was certainly influenced by outdoor levels but human activities played a key role causing a worsening of indoor air quality. The concentration decrease rates of fine particles (the most harmful) were lower than those of the coarse fraction; therefore, the effects were still appearing even after the end of the activities that generated it. According to the latest guidelines, the average concentrations of $\mathrm{CO}_{2}$ measured between $990 \mathrm{ppm}$ and $1,318 \mathrm{ppm}$ suggested a low standard of comfort of building occupants, which may suffer from headaches, drowsiness and attention deficit.

In recent years, the portable sensors have produced a great potential in creating extended monitoring networks in real time; however, a progress in reliability of data is needed.

Keywords: carbon dioxide, Grimm 1.108, indoor air quality, particulate matter, Sensordrone.
\end{abstract}

\section{INTRODUCTION}

The scientific interest in indoor pollution has been increasing since the second half of the 1980s [1-3]. Indoor air pollution is an important global risk factor requiring increasing efforts in the field of research and policy-making [4]. Several previous studies have found that people spend up to $80 \%$ of their time in indoor environments [5-7]. In many cases, most building occupants do not realize that indoor air pollution can significantly affect their health in addition to ambient air pollutants [8-10]. According to the World Health Organization (WHO) [11], individuals who are exposed to indoor pollutants will be more vulnerable compared to those exposed to outdoor air pollutants in the long term. Many studies have shown that exposure to atmospheric particulate matter (PM) is associated with adverse health impacts such as heart and respiratory diseases [12]. The percentage of particle deposition in different regions of the respiratory system directly depends upon the particle size [13]. Coarse particles $\left(\mathrm{PM}_{10}\right.$, diameter $<10 \mu \mathrm{m}$ ) have been associated with respiratory hospital admission [14]. Fine PM $\left(\mathrm{PM}_{2.5}\right.$, diameter $\left.<2.5 \mu \mathrm{m}\right)$ has been more strongly correlated with cardiovascular and respiratory effects [15]. Ultrafine particles (UFP, diameter $<0.1 \mu \mathrm{m}$ ) can penetrate deeply into the alveolar regions of the lungs [16]. Along with physical properties (e.g., size and mass), chemical composition (e.g., organic carbon, elemental carbon, sulfate and nitrate salts, metals) also affects the toxicity of PM [15]. 
According to the EU current standard on PM (Directive 2008/50/EC), which refers only to outdoor air quality (OAQ), the annual average concentration $\left(40 \mu \mathrm{g} \mathrm{m}^{-3}\right.$ for $\mathrm{PM}_{10}$ and $25 \mu \mathrm{g} \mathrm{m}^{-3}$ for $\mathrm{PM}_{2.5}$ ), the maximum outdoor 24-hour average concentrations allowed for $\mathrm{PM}_{10}\left(50 \mu \mathrm{g} \mathrm{m}^{-3}\right)$ and the number of days exceeding (35) are fixed [17]. In the US, instead, the EPA limits the yearly $\mathrm{PM}_{2.5}$ value to $12 \mu \mathrm{g} \mathrm{m}^{-3}$ and fixes the daily (24-hour) standard at $35 \mu \mathrm{g} \mathrm{m}^{-3}$ and $150 \mu \mathrm{g} \mathrm{m}^{-3}$ for $\mathrm{PM}_{2.5}$ and $\mathrm{PM}_{10}$ respectively [18].

With regard to the indoor air quality (IAQ), several EU and non-EU countries have set specific values that are normally based upon ambient outdoor concentration. However, there are still EU countries, such as Italy, that do not have a national legislation for IAQ environments [19].

The American Standard ASHRAE [20] gives a further contribution to the field with the advantage of indicating precise values of concentrations: $\mathrm{PM}_{2.5}$ is set to $15 \mu \mathrm{g} \mathrm{m}^{-3}$ (annual exposure) and $35 \mu \mathrm{g} \mathrm{m}^{-3}$ (daily exposure), whereas limit for $\mathrm{PM}_{10}$ are $50 \mu \mathrm{g} \mathrm{m}^{-3}$ (annual exposure) and $150 \mu \mathrm{g} \mathrm{m}^{-3}$ (daily exposure).

Carbon dioxide $\left(\mathrm{CO}_{2}\right)$ is a normal constituent of exhaled breath and is commonly measured as a screening tool to evaluate whether adequate volumes of fresh outdoor air are being introduced into indoor air. The outdoor level of carbon dioxide is usually from 300 parts per million (ppm) to $400 \mathrm{ppm}$ [20]. The carbon dioxide level is usually greater inside a building than outside, even in building with few complaints about indoor air quality (e.g. PM and other air pollutants).

The ad hoc working group of the Indoor Air Hygiene Commission and the Working Group of the Supreme Health Authorities of the Federal States (IRK/AOLG ad hoc working group) has produced an evaluation for $\mathrm{CO}_{2}$ in indoor air [21]. According to this, values for $\mathrm{CO}_{2}$ concentrations in indoor air are laid down, which are to be seen as snapshot values pertaining to the concentration at a given moment in time. Assuming a reference temperature of $25^{\circ} \mathrm{C}$, $\mathrm{CO}_{2}$ levels are divided into "hygienically insignificant" $(<1,000 \mathrm{ppm})$, "hygienically evident" $(1,000 \div 2,000 \mathrm{ppm})$ and "hygienically unacceptable" ( $>2,000 \mathrm{ppm})$. If a $\mathrm{CO}_{2}$ value of $1,000 \mathrm{ppm}$ is exceeded the room should be aired; if $2,000 \mathrm{ppm}$ is exceeded it must be aired. In both cases, the aim should be to remain below 1,000 ppm [22].

Also the Occupational Safety and Health Administration (OSHA) standard for $\mathrm{CO}_{2}$, with regard to safety at work, can be used. The OSHA standards is an 8-hour time-weighted average (TWA) of 5,000 ppm with a short-term 15-minute average limit of 30,000 ppm [20].

$\mathrm{CO}_{2}$ has a continuum of effects that range from physiologic (e.g., ventilatory simulation) to toxic (e.g., cardiac acidosis and anoxia). The effects of $\mathrm{CO}_{2}$ in a specific individual depend on the concentration and duration of exposure as well as individual factors, such as age, health, physiologic make-up, physical activity, occupation and lifestyle. With high-level $\mathrm{CO}_{2}$ exposure, the displacement of $\mathrm{O}_{2}$ by $\mathrm{CO}_{2}$ significantly contributes to toxicity. Signs of asphyxia are evident when the atmospheric $\mathrm{O}_{2}$ is $\leq 16 \%$ [23]. Almost immediate unconsciousness leading to death occurs in humans ate rest when the $\mathrm{O}_{2}$ is reduced to 10 to $13 \%$. Strenuous physical exertion increases the threshold [24].

Traditionally, air pollution has been measured by expensive, stationary and complex air-monitoring instrumentation. Consequently, this limits the amount of environmental data that is often available for exposure and health assessment. As air quality management becomes more complex, there is a need for enhanced exposure monitoring capabilities. Rapid development in technology led to the production of small, low-cost air pollution sensors; these new technologies, used by academics, industry, communities and individuals, symbolize the future of air quality monitoring [25-27]. 
This study investigated the exposure to a range of particle $\mathrm{PM}_{10}, \mathrm{PM}_{2.5}$ and $\mathrm{PM}_{1}$ sizes and the $\mathrm{CO}_{2}$ levels in indoor places. The aim was to evaluate IAQ in the environments where people spend most of the day (e.g., offices, bedrooms), sites that usually are not monitored.

\section{MATERIALS AND METHODS}

The instrument used for PM measurements was the GRIMM analyzer 1.108 [28]. This portable dust aerosol spectrometer has been built for continuous measurement of airborne particles as well as for measuring the particle count distribution. The measuring principle of the model is light scattering of single particles with a semiconductor laser as the light source. Inside the measuring cell, the scattering light is led directly and via a mirror with a wide opening angle onto the detector. The detector is positioned at right angles to the incident laser beam. If a particle crosses the laser beam, it creates a light pulse. The signal of the detector diode will be classified into different size channels after accordant amplification. Model 1.108 possesses 15 size channels from 0.3 to $20 \mu \mathrm{m}$. This way the particle size distribution can be measured which provides the basis for the calculation of the dust mass [29].

The data are available in the time intervals between 6 and 60 seconds, and, in this paper, the $\mathrm{PM}_{10}, \mathrm{PM}_{2.5}$ and $\mathrm{PM}_{1}$ values were monitored. Even though, a current regulation does not recognize this method as official [30] because it suggests adopting gravimetric methods, the GRIMM analyzer is able to provide a good overview about IAQ of the environment object to study.

The levels of PM were measured every 60 seconds, in winter, in six situations: two offices, two printer rooms and two bedrooms.

The first case is represented by an open space room (test 1A): $16.50 \mathrm{~m}$ long and $7.30 \mathrm{~m}$ wide, with four workstations and one photocopier working; then the instrument was placed on a shelf in the center of the space at a height of $1.15 \mathrm{~m}$. Another test was performed in a smaller office (test 1B) with still four workstations and one laser printer. In this case, the measurements were $3.8 \mathrm{~m} \times 6.5 \mathrm{~m}$; the instrument was placed at a height of $1.25 \mathrm{~m}$.

Moreover, two printer rooms inside two public libraries were analyzed. In the first case (test $2 \mathrm{~A}$ ), four printers were present in a $3.30 \times 2.70 \mathrm{~m}$ room and the instrument was placed at a height of $0.8 \mathrm{~m}$. Instead, the test $2 \mathrm{~B}$ was done in a $4.10 \mathrm{~m} \times 5.70 \mathrm{~m}$ room with three printers and two plotters.

The last two tests investigated the variation in PM concentrations in two single bedrooms, having an area of $10 \mathrm{~m}^{2}$ and different types of windows. The aim was to investigate their different insulation. In the first room (test $3 \mathrm{~A}$ ), there was a wooden double-pane window, instead the second case (test 3B) had a wood simple-pane window. In both cases, the instrument was placed at a height of $1.00 \mathrm{~m}$.

The low-cost instrument chosen for the $\mathrm{CO}_{2}$ measurements is the portable multi-sensor Sensordrone. It is a pocket-sized device connected wireless to a smartphone. This sensor contains an array of sensors, enabling it to be used as a carbon monoxide detector, natural gas leak detector, stud finder, light intensity monitor, color detector, thermometer/temperature reader, barometric pressure and humidity monitor. Each type of measurement is processed by a specific sub-system [31]. In addition to the ease of expansion on the software side, the Sensordrone also has an additional connector that allows other sensors not included in the device to be hooked up to it. It is the case of $\mathrm{CO}_{2}$. The sensor can be turned into a complete IAQ or greenhouse monitor. Sensordrone can monitor $\mathrm{CO}_{2}$ in addition to all the already included sensors. The $\mathrm{CO}_{2}$ sensor, based on non-dispersive infrared (NDIR), has a resolution of $1 \mathrm{ppm}$, a range between 0 and 2,000 ppm, an accuracy of $50 \mathrm{ppm}$ and a response time from 30 seconds to 3 minutes [31]. 
$\mathrm{CO}_{2}$ values were measured in four different situations: an office, a computer-room and two bedrooms.

In the first case (test $4 \mathrm{~A}$ ), the office was the same of test $1 \mathrm{~B}$ and the instrument was placed at a height of $1.25 \mathrm{~m}$. The computer-room (test 4B) had an area of $200 \mathrm{~m}^{2}$ and about 80 workstations. The sensor was placed in the middle of the room, at a height of $1.00 \mathrm{~m}$. The last two case studies (tests $5 \mathrm{~A}$ and $5 \mathrm{~B}$ ) were carried out in the same rooms of tests $3 \mathrm{~A}$ and $3 \mathrm{~B}$ respectively, where the sensor was located at $1.00 \mathrm{~m}$ above the floor.

\section{RESULTS AND DISCUSSIONS}

The results of the tests are given below through the graphs of the measurements, a summary table and the discussions of the trends (Tables 1-4).

Table 1: Maximum, average and minimum concentrations of PM for tests 1A and 1B.

\begin{tabular}{lccc}
\hline & & $\mathbf{1 A}$ & $\mathbf{1 B}$ \\
open space & & $\begin{array}{c}\text { office } \\
\text { small independent } \\
\text { office }\end{array}$ \\
\cline { 3 - 4 } Maximum $\left(\mu \mathrm{g} \mathrm{m}^{-3}\right)$ & $\mathbf{P M}_{\mathbf{1 0}}$ & $\mathbf{1} \mathbf{~ h}$ & $\mathbf{1 ~ h}$ \\
& $\mathbf{P M}_{\mathbf{2 . 5}}$ & 7.4 & 6.3 \\
& $\mathbf{P M}_{\mathbf{1}}$ & 1.2 & 2.0 \\
Average $\left(\mu \mathrm{g} \mathrm{m}^{-3}\right)$ & $\mathbf{P M}_{\mathbf{1 0}}$ & 0.8 & 1.6 \\
& $\mathbf{P M}_{\mathbf{2 . 5}}$ & 3.5 & 2.2 \\
& $\mathbf{P M}_{\mathbf{1}}$ & 0.8 & 1.5 \\
& $\mathbf{P M}_{\mathbf{1 0}}$ & 0.5 & 1.3 \\
Minimum $\left(\mu \mathrm{g} \mathrm{m}^{-3}\right)$ & $\mathbf{P M}_{\mathbf{2 . 5}}$ & 0.5 & 1.3 \\
& $\mathbf{P M}_{\mathbf{1}}$ & 0.3 & 1.3 \\
& & 0.3 & 1.2 \\
\hline
\end{tabular}

Table 2: Maximum, average and minimum concentrations of PM for tests 2A and 2B.

\begin{tabular}{lccc}
\hline & & $\mathbf{2 A}$ & $\mathbf{2 B}$ \\
printers room & (library) & $\begin{array}{c}\mathbf{2 B} \\
\text { printers room } \\
\text { (university) }\end{array}$ \\
\cline { 3 - 4 } Maximum $\left(\mu \mathrm{g} \mathrm{m}^{-3}\right)$ & $\mathbf{P M}_{\mathbf{1 0}}$ & $\mathbf{1 ~ h}$ & $\mathbf{1 ~ \mathbf { ~ }}$ \\
\hline & $\mathbf{P M}_{\mathbf{2 . 5}}$ & 33.0 & 35.7 \\
& $\mathbf{P M}_{\mathbf{1}}$ & 4.9 & 5.8 \\
Average $\left(\mu \mathrm{g} \mathrm{m}^{-3}\right)$ & $\mathbf{P M}_{\mathbf{1 0}}$ & 3.6 & 5.1 \\
& $\mathbf{P M}_{\mathbf{2 . 5}}$ & 17.1 & 15.7 \\
& $\mathbf{P M}_{\mathbf{1}}$ & 4.0 & 3.6 \\
Minimum $\left(\mu \mathrm{g} \mathrm{m}^{-3}\right)$ & $\mathbf{P M}_{\mathbf{1 0}}$ & 3.2 & 2.6 \\
& $\mathbf{P M}_{\mathbf{2 . 5}}$ & 9.5 & 7.1 \\
& $\mathbf{P M}_{\mathbf{1}}$ & 3.4 & 0.9 \\
& & 2.9 & 0.5 \\
\hline
\end{tabular}


Table 3: Maximum, average and minimum concentrations of PM for tests 3A and 3B.

\begin{tabular}{lccc}
\hline & & 3A & 3B \\
& & $\begin{array}{c}\text { double-pane windows } \\
\text { bedroom }\end{array}$ & $\begin{array}{c}\text { simple-pane windows } \\
\text { bedroom }\end{array}$ \\
\cline { 3 - 4 } & & $\mathbf{8 ~ h}$ & $\mathbf{8 ~ h}$ \\
\hline Maximum $\left(\mu \mathrm{g} \mathrm{m}^{-3}\right)$ & $\mathbf{P M}_{\mathbf{1 0}}$ & 35.4 & 83.7 \\
& $\mathbf{P M}_{\mathbf{2 . 5}}$ & 13.3 & 42.2 \\
& $\mathbf{P M}_{\mathbf{1}}$ & 11.7 & 38.6 \\
Average $\left(\mu \mathrm{g} \mathrm{m}^{-3}\right)$ & $\mathbf{P M}_{\mathbf{1 0}}$ & 5.8 & 36.4 \\
& $\mathbf{P M}_{\mathbf{2 . 5}}$ & 2.9 & 24.3 \\
& $\mathbf{P M}_{\mathbf{1}}$ & 2.4 & 21.8 \\
Minimum $\left(\mu \mathrm{g} \mathrm{m}^{-3}\right)$ & $\mathbf{P M}_{\mathbf{1 0}}$ & 1.6 & 21.7 \\
& $\mathbf{P M}_{\mathbf{2 . 5}}$ & 1.6 & 16.6 \\
& $\mathbf{P M}_{\mathbf{1}}$ & 1.3 & 14.9 \\
\hline
\end{tabular}

Table 4: Maximum, average and minimum concentrations of $\mathrm{CO}_{2}$ for tests $4 \mathrm{~A}$ and 4B.

\begin{tabular}{llcc}
\hline & & $\begin{array}{c}\mathbf{4 A} \\
\text { small independent } \\
\text { office }\end{array}$ & $\begin{array}{c}\mathbf{4 B} \\
\text { computer-room } \\
\text { (university) }\end{array}$ \\
\cline { 3 - 4 } & Maximum (ppm) & $\mathbf{1 ~ h}$ & $\mathbf{1 ~ h}$ \\
\hline \multirow{2}{*}{$\mathbf{C O}_{2}$} & Average $(\mathrm{ppm})$ & 687 & 1,666 \\
& Minimum $(\mathrm{ppm})$ & 623 & 1,318 \\
& & 558 & 640 \\
\hline
\end{tabular}

In the analyzed offices, the IAQ resulted of good quality. In particular, in test 1B (Fig. 1) the $\mathrm{PM}_{10}$ concentration has always been lower than $7 \mu \mathrm{g} \mathrm{m}^{-3}$. The activities of turning on the heating system (a vertical fun coil unit) and printing were clearly indicated by the peaks of $\mathrm{PM}_{10}$ at 15:05 and $\mathrm{PM}_{1}$ at 15:45, respectively.

In test $1 \mathrm{~A}$ (Fig. 1) the highest recorded values of $\mathrm{PM}_{10}$ can be explained by the location of the building in a more congested area; however, the concentrations of PM have never exceeded the threshold values suggested by the ASHRAE Standard.

In both cases, a poor re-suspension of dust was observed despite the transit of workers and a few door openings.

In test 2A (Fig. 2) the time when study room was left to get into the printers room was distinctly shown by the step of $\mathrm{PM}_{2.5}$ and $\mathrm{PM}_{1}$ concentrations. This is probably due to small changes in ventilation.

The same phenomenon occurred during a number of printing sessions in test $2 \mathrm{~B}$ (Fig. 2). The area object of the study was not an enclosed environment: IAQ benefited from the large window on the hallway, useful for air circulation. The risk from the presence of fine particles 

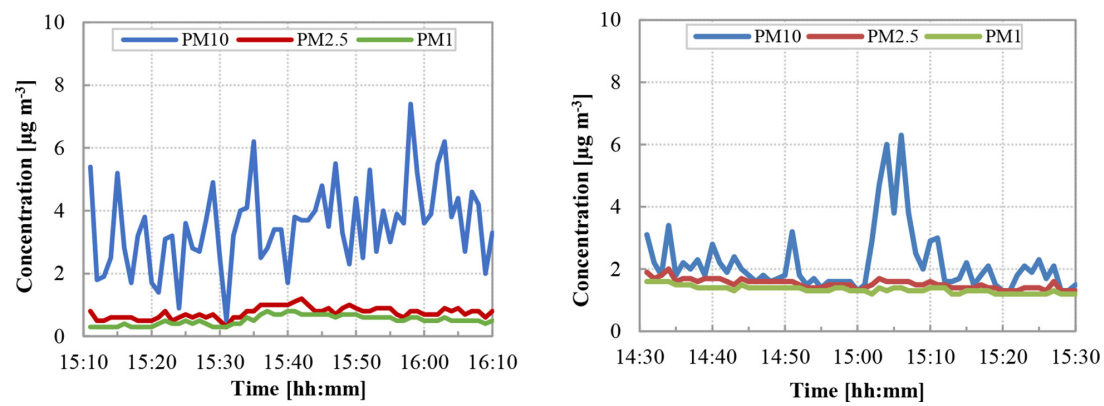

Figure 1: Concentration profiles of $\mathrm{PM}_{10}, \mathrm{PM}_{2.5}, \mathrm{PM}_{1}$ during test $1 \mathrm{~A}(\mathrm{~L})$ and test $1 \mathrm{~B}(\mathrm{R})$.
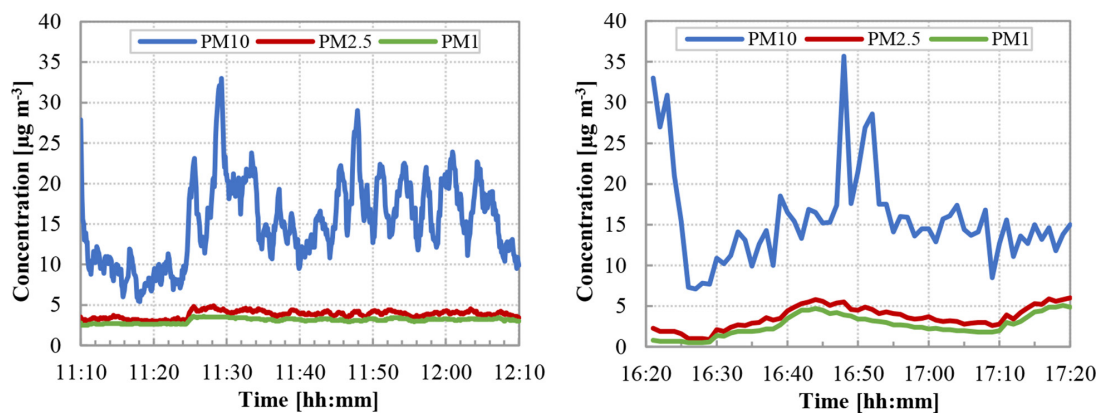

Figure 2: Concentration profiles of $\mathrm{PM}_{10}, \mathrm{PM}_{2.5}, \mathrm{PM}_{1}$ during test 2A (L) and test 2B (R).
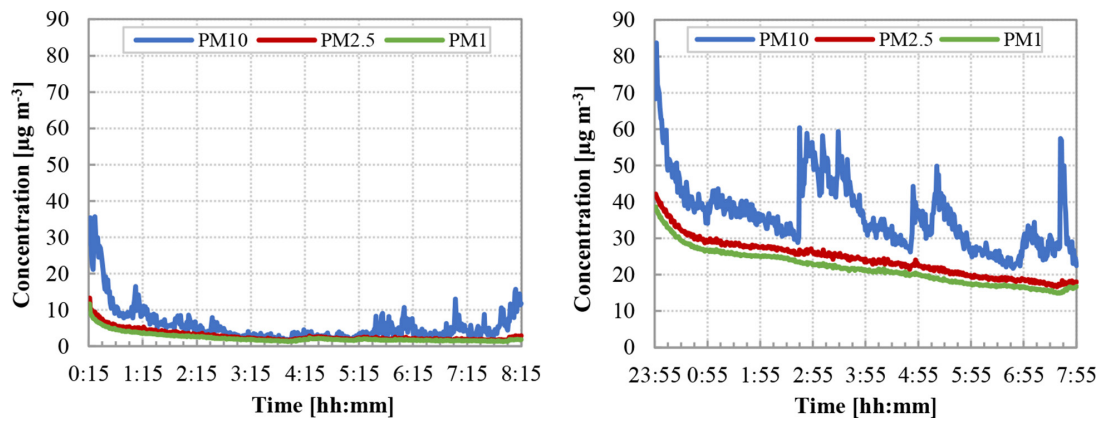

Figure 3: Concentration profiles of $\mathrm{PM}_{10}, \mathrm{PM}_{2.5}, \mathrm{PM}_{1}$ during test 3A (L) and test 3B (R).

did not decrease with the end of printing operations because the concentrations did not go back to pre-activity values in a short time.

In both tests, the oscillating values of $\mathrm{PM}_{10}$ were due to movements of the occupants of the room, which caused the re-suspension of coarse particles.

As expected, in test 3A (Fig. 3), the concentration of particles decreased during the night and finally resumed growing in correspondence of the beginning of morning activities. The removal velocity by deposition was higher for coarse particles: they had a fast variation compared with a slow decrease of the fine fraction because $\mathrm{PM}_{2.5}$ and $\mathrm{PM}_{1}$ were less influenced by the movements. The "background concentrations" were moderate: the reason is due to the fact that the 13th floor apartment has double-pane windows and is located in a residential area. 
An entirely different situation was observed in test 3B (Fig. 3): the street level room was in an apartment house placed in an urban area and the single-pane window provided less isolation from the outdoor environment. In addition, a foggy day just before the measurement period contributed to stagnation of the pollutants: after an aeration phase at the beginning of the test, IAQ was of bad quality with $\mathrm{PM}_{10}, \mathrm{PM}_{2.5}$ and $\mathrm{PM}_{1}$ concentrations reaching $83.7 \mu \mathrm{g} \mathrm{m}^{-3}, 42.2 \mu \mathrm{g} \mathrm{m}^{-3}$ and $37.6 \mu \mathrm{g} \mathrm{m}^{-3}$, respectively.

The greater fluctuations of the $\mathrm{PM}_{10}$ concentration during test $5 \mathrm{~B}$ confirmed a strong relationship between indoor and outdoor environments, particularly in the case of poor insulation.

As regards of $\mathrm{CO}_{2}$ concentrations, the results obtained for the various tests are reported.

As shown in Fig. 4, the concentration of $\mathrm{CO}_{2}$ was almost steady and never exceeded $800 \mathrm{ppm}$ despite the presence of four occupants simultaneously in the office during test 4A.

Data of test 4B (Fig. 4) demonstrated that IAQ will get worse in the presence of a high number of people in indoor environments. The concentration of $\mathrm{CO}_{2}$ constantly grew to reach a peak of 1,700 ppm during the lesson started at 14:30 (about 40 students in the room). This underlined the insufficient air renewal, exclusively due to the occasional opening of the three doors while the windows were closed because of the cold outside.

As a result of non-renewal of the air, in both cases (5A and 5B) the trend of the concentration was upward during the night, but unexpectedly the higher average values occurred in test 5B (Fig. 5); an explanation could be the shortest distance between the instrument and the headboard.

The sharp drop of about $600 \mathrm{ppm}$ was a consequence of the door opening in the morning.
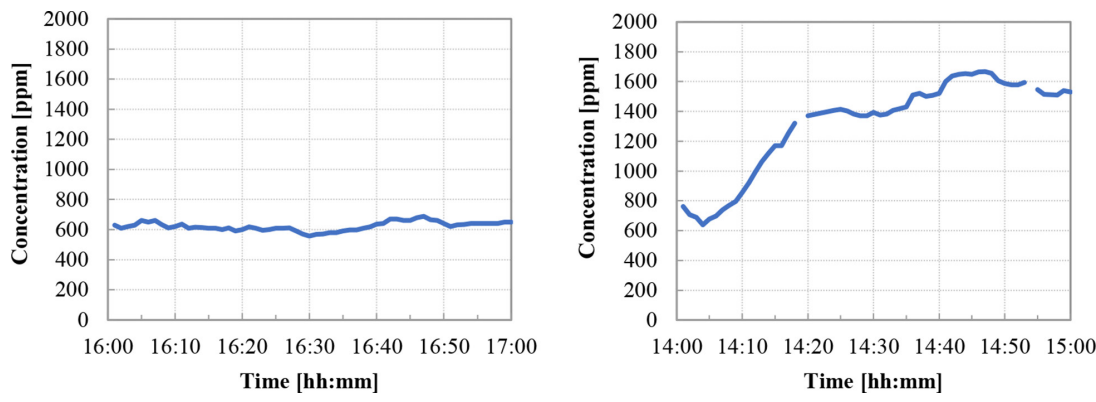

Figure 4: Concentration profile of $\mathrm{CO}_{2}$ during test $4 \mathrm{~A}(\mathrm{~L})$ and test $4 \mathrm{~B}(\mathrm{R})$.
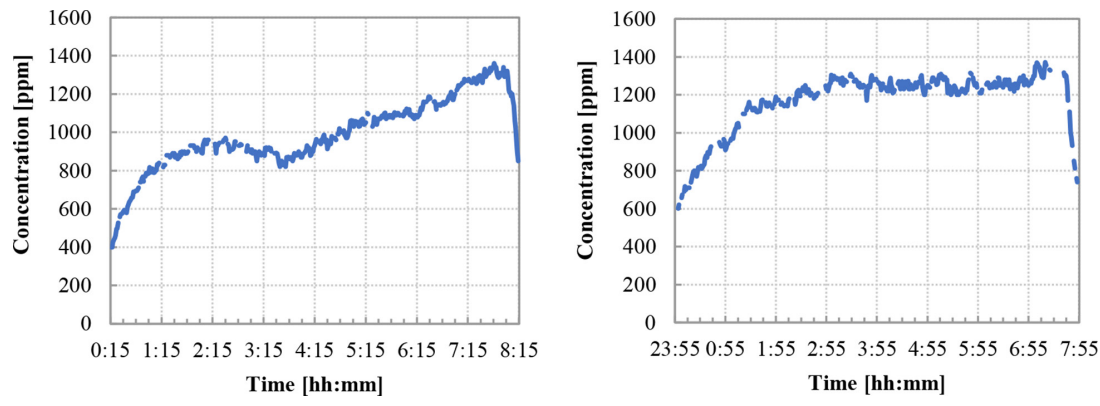

Figure 5: Concentration profile of $\mathrm{CO}_{2}$ during test $5 \mathrm{~A}(\mathrm{~L})$ and test $5 \mathrm{~B}(\mathrm{R})$. 
Table 5: Maximum, average and minimum concentrations of $\mathrm{CO}_{2}$ for tests 5A and 5B.

\begin{tabular}{cccc}
\hline & & $\mathbf{5 A}$ & $\mathbf{5 B}$ \\
& & $\begin{array}{c}\text { double-pane windows } \\
\text { bedroom }\end{array}$ & $\begin{array}{c}\text { simple-pane windows } \\
\text { bedroom }\end{array}$ \\
\cline { 3 - 4 } & & $\mathbf{8} \mathbf{~ h}$ & $\mathbf{8 ~ h}$ \\
\hline $\mathbf{C O}_{2}$ & Maximum (ppm) & 1,360 & 1,372 \\
& Average (ppm) & 990 & 1,175 \\
& Minimum (ppm) & 400 & 588 \\
\hline
\end{tabular}

\section{CONCLUSIONS}

The series of tests contributed to investigate the human exposure to $\mathrm{PM}_{10}, \mathrm{PM}_{2.5}, \mathrm{PM}_{1}$ and $\mathrm{CO}_{2}$ in indoor places where people spend most of the day. It was proved that IAQ is adversely affected by the crowding of people and their daily activities.

In tests $1 \mathrm{~A}$ and $1 \mathrm{~B}$, the concentrations of PM were well below the threshold values proposed by the ASHRAE Standard; in this regard, a regular maintenance and replacement of filters of the heating system is of fundamental importance.

As expected, test 3B showed that the indoor PM level was strongly influenced by the outdoor environment in the absence of a proper protection as pointed out by both the background concentrations and the temporal fluctuations in the absence of internal activities. Results seem to confirm the positive role of double-pane windows as an insulating barrier to airflow.

In tests $2 \mathrm{~A}$ and $2 \mathrm{~B}$, the analysis of the time profile of particle concentrations indicated that the concentration decrease rates of fine particles were lower than the one of coarse fraction. This means that concentrations of $\mathrm{PM}_{2.5}$ and $\mathrm{PM}_{1}$ remained high even at the end of the activities that generated it.

With the aim of improving the IAQ in an office, the main rule to follow is an efficient design of space including the planning solution of concentrate all electronic equipment in a separated room with a dedicated air aspiration system.

The phenomenon of dust re-suspension, which occurred in every monitored area should be limited: for this reason, cleaning activities for offices may be optimized also adopting specific guidelines to prevent it.

$\mathrm{CO}_{2}$ is the main metabolic gas produced by humans as a by-product of breathing and often it can be seen as a marker suggesting inadequate ventilation in relation to indoor occupant density. In this article, $\mathrm{CO}_{2}$ indoor was analyzed in order to point out its importance as a parameter to be monitored in addition to conventional pollutants typically checked: low PM concentrations could not be sufficient to guarantee a good IAQ.

The 8-hour average limit set by OSHA Standard has never exceeded but according to IRK/ AOLG ad hoc working group, the $\mathrm{CO}_{2}$ average concentrations of $1,318 \mathrm{ppm}$ (test 4B), $990 \mathrm{ppm}$ (test $5 \mathrm{~A}$ ) and 1,175 ppm (test 5B) suggested a low standard of comfort of building occupants which may cause headaches, drowsiness and attention deficit.

Ensuring a regular ventilation and air renewal is the best way to limit the indoor $\mathrm{CO}_{2}$ concentrations; the simple act of keeping the door open improved the IAQ by increasing the available volumes of air during the night. The tendency to keep windows closed makes the 
winter time the most adverse: for this reason, using an automatic ventilation system should be advisable in new buildings, preferably equipped with heat recovery mode.

The entry market of a wide range of low-cost sensors can lead to the development of extensive monitoring networks in order to have further information of the real human exposure to air pollutants. In the future, other public places and daily activities could be investigated and it would be better if cooperation between health experts and policy makers were promoted with the purpose of achieving common and shared IAQ guidelines.

Finally, it must be underlined that the results presented in this paper must be considered preliminary as a small dataset has been used and $\mathrm{CO}_{2}$ and $\mathrm{PM}$ have not been measured simultaneously.

\section{REFERENCES}

[1] Samet, J.M. \& Spengler, J.D., Indoor environments and health: moving into the 21st century. Journal of Public Health, 93(9), pp. 1489-1493, 2003. http://dx.doi.org/10.2105/ajph.93.9.1489

[2] Ionescu, G., Apostol, T., Rada, E.C., Ragazzi. M. \& Torretta, V., Critical analysis of strategies for PM reduction in urban areas. UPB Scientific Bulletin, Series D, 75(2), pp. 175-186, 2013.

[3] Torretta, V., Raboni, M., Copelli, S., Rada, E.C., Ragazzi, M., Ionescu, G., Apostol, T. \& Badea, A., Application of strategies for particulate matter reduction in urban areas: an italian case. UPB Scientific Bulletin, Series D, 75(4), pp. 221-228, 2013.

[4] Bruce, N., Perez-Padilla, R. \& Albalak, R., Indoor air pollution in developing countries: a major environmental and public health challenge. Bull World Health Organ, 78(9), pp. 1078-1092, 2000.

[5] Du, L., Batterman, S., Parker, E., Godwin, C., Chin, J.Y., O’Toole, A., Robins, T., Brakerfield-Caldwell, W. \& Lewis, T., Particle concentration and effectiveness of freestanding air filters in bedrooms of children with asthma in Detroit, Michigan. Building and Environment, 46(11), pp. 2303-2313, 2011.

http://dx.doi.org/10.1016/j.buildenv.2011.05.012

[6] Rada, E.C., Ragazzi, M., Antolini, D., Malloci, E. \& Venturi, M., In-door air measurements of PM10 in different conditions. Proceedings of International Symposium on Environmental Science and Technology, pp. 571-577, 2009.

[7] Ragazzi, M., Rada, E.C., Zanoni, S. \& Andreottola, G., Role of particulate matter in offices for urban air quality management. WIT Transactions on Ecology and the Environment, 191, pp. 1403-1412, 2014.

http://dx.doi.org/10.2495/SC141182

[8] United States Environmental Protection Agency (USEPA). Air quality criteria for particulate matter: dosimetry of inhaled particles in the respiratory tract. Washington DC: United States Environmental Protection Agency (USEPA), 1997.

[9] Fish, W.J., Review of some effects of climate change on indoor environmental quality and health and associated no-regrets mitigation measures. Building and Environment, 86, pp. 70-80, 2015. http://dx.doi.org/10.1016/j.buildenv.2014.12.024

[10] Laumbach, R., Mang, Q. \& Kipen, H., What can individuals do to reduce personal health risks from air pollution? Journal of Thoracic Disease, 7(1), pp. 96-107, 2015.

[11] WHO, Health aspects related to indoor air quality. Report on a WHO working group, Geneva: World Health Organization (WHO), 1989. 
[12] Pope III, C.A. \& Dockery, D.W., Health effects of fine particulate air pollution: lines that connect. Journal of the Air \& Waste Management Association, 56(6), pp. 709-742, 2006. http://dx.doi.org/10.1080/10473289.2006.10464485

[13] Arhami, M., Minguillón, M., Polidori, A., Schauer, J., Delfino, R. \& Sioutas, C., Organic compound characterization and source apportionment of indoor and outdoor quasi-ultrafine particulate matter in retirement homes of the Los Angeles Basin. Indoor Air, 20(1), pp. 17-30, 2010. http://dx.doi.org/10.1111/j.1600-0668.2009.00620.x

[14] Brunekreef, B. \& Forsberg, B., Epidemiological evidence of effects of coarse airborne particles on heath. European Respiratory Journal, 26(2), pp. 309-318, 2005. http://dx.doi.org/10.1183/09031936.05.00001805

[15] Bell, M.L., Assessment of the Health Impacts of Particulate Matter Characteristics. Research report, Health Effects Institute, p. 5, 2012.

[16] Siutas, M., Delfino, R.J. \& Singh, M., Exposure assessment for atmospheric ultrafine particles (UFPs) and implications in epidemiologic research. Environmental Health Perspectives, 113(8), pp. 947-955, 2005. http://dx.doi.org/10.1289/ehp.7939

[17] European Parliament and Council of the European Union, available at: http://eur-lex. europa.eu/legal-content/EN/TXT/?uri=CELEX:32008L0050

[18] United States Environmental Protection Agency (EPA), available at: www3.epa.gov/

[19] Ionescu, G. \& Stefani, P., Environmental assessment of waste transport and treatment: a case study. WIT Transactions on Ecology and the Environment, 180, pp. 175-185, 2014. http://dx.doi.org/10.2495/WM140151

[20] ASHRAE, Ventilation for Acceptable Indoor Air Quality. ANSI/ASHRAE Standard 62.1, 2007.

[21] Ad-hoc AG IRK/AOLG, Gesundheitliche Bewertung von Kohlendioxid in der Innenraumluft [Health evaluation of carbon dioxide in indoor air]. Bundesgesundheitsblatt - Gesundheitsforschung - Gesundheitsschutz, 51, pp. 1358-1369, 2008. http://dx.doi.org/10.1007/s00103-008-0707-2

[22] German Federal Environment Agency's Indoor Air Hygiene Commission. Guidelines for Indoor Air Hygiene in School Buildings, KOMAG mbH: Berlin, 2008.

[23] Hazardous Substances Databank (HSDB). A databse of the National Library of Medicine's TOXNET system, available at: http://toxnet.nlm.nih.gov, 2003.

[24] Schauf, C.L., Moffett, D.F. \& Moffett, S.B., Human Physiology. St. Louis, MO: Times Mirror/Mosby College Publishing, pp. 436, 1990.

[25] United States Environmental Protection Agency (EPA), www.epa.gov/air-research/.

[26] Rada, E.C., Ragazzi, M., Brini, M., Marmo, L., Zambelli, P., Chelodi, M. \& Ciolli, M., Perspectives of low-cost sensors adoption for air quality monitoring. UPB Scientific Bulletin, series D, 75(2), pp. 243-250, 2012.

[27] Piedrahita, R., Xiang, Y., Masson, N., Ortega, J., Collier, A., Jiang, Y., Li, K., Dick, R.P., Lv, Q., Hannigan, M. \& Shang, L., The next generation of low-cost personal air quality sensors for quantitative exposure monitoring. Atmospheric Measurement Techniques, 7, pp. 3325-3336, 2014. http://dx.doi.org/10.5194/amt-7-3325-2014

[28] GRIMM Aerosol, available at: www.grimm-aerosol.com/en/Indoor-AirQuality/2/2/index.html. 
[29] Peters, T.M., Ott, D. \& O'Shaughnessy, P.T., Comparison of the Grimm 1.108 and 1.109 Portable Aerosol Spectrometer to the TSI 3321 aerodynamic, particle sizer for dry particles. Annals of Occupational Hygiene, 50(8), pp. 843-850, 2006. http://dx.doi.org/10.1093/annhyg/mel067

[30] Schiavon, M., Rada, E.C., Ragazzi, M. \& Antolini, D., Indoor measurements of particulate matter during beef-steak cooking under different conditions. WIT Transaction on Ecology and Environment, 176, pp. 255-264, 2013.

[31] Sensorcon. Make Sensordrone Do Even More, available at: http://www.sensorcon.com/ sensordrone-extensions/ 